\title{
Tip 2 Diyabetes Mellituslu Hastaların Hastalıklarına Yönelik Tutum ve Davranışlarının İncelenmesi
}

\section{Investigation of the Attitudes and Behaviors of Patients with Type 2 Diabetes Mellitus}

\author{
iD Ahmet Kayabaş ${ }^{1}$, iD Yasemin Korkut ${ }^{1}$ \\ ${ }^{1}$ Kütahya Sağlık Bilimleri Üniversitesi Tıp Fakültesi Aile Hekimliği AD
}

\section{Öz}

Amaç: Bireylerin hastalıklarını algılaması, hastalığa karșı tutumları, hastalıkla baș etme yöntemleri üzerinde önemli etkiye sahiptir. Araștırma Tip 2 Diyabetes Mellitus'lu hastaların hastalıklarına yönelik tutum ve davranışlarını değerlendirmek amacıyla yapılmıştır. Yöntem: Araştırma, kesitsel bir çalışmadır. Hastaların yazılı onamları alındıktan sonra veri toplama aracı olan Sosyodemografik Özellikler Formu, Klinik Veriler Formu, Diyabet Tutum Ölçeği ve Yaşam Doyum Ölçeği’ni içeren anket formu yüz yüze görüşme tekniği ile uygulanmıştır.

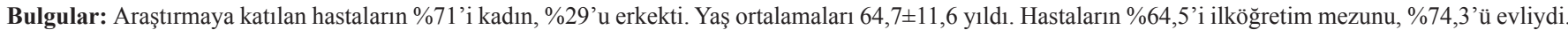
Klinik özelliklerinin dağılımına bakıldığında, \%50,3’ü < 10 yıldır diyabet hastasıydı, \%25,7'si insülin kullanıyordu, \%14,8'inde diyabetik ayak vardı. Hastaların diyabet tutum ölçeği puan ortalaması 3,61 $\pm 0,41$ idi. Hastaların yaşları, aylık gelir düzeyleri, diyabet tanısı almış olma süreleri ile diyabet tutum ölçeği puanları arasında istatistiksel olarak anlamlı fark vardı. Yaşam doyum ölçeği puanları ile hastaların yaşları, eğitim durumları, medeni durumları ve ailelerinde diyabet hastası birey olması durumu arasında anlamlı fark vardı. Hastaların diyabet tutum ölçeği ve yaşam doyum ölçeği puanları arasında pozitif yönlü zayıf korelasyon saptandi.

Sonuç: diyabette hastalığa daha uyumlu ve pozitif tutuma sahip bireylerin yaşam doyumları da daha yüksek olduğundan, hastalarda negatif ve pozitif tutuma neden olan faktörlerin saptanarak bireylerin bu konularda uygun şekilde desteklenmeleri önemlidir.

Anahtar Kelimeler: Tip 2 diyabet, evde bakım, tutum, yaşam doyumu

\begin{abstract}
Objective: Individuals' perception of their disease, has an important effect on the methods of coping with the disease. The study was conducted to evaluate the attitudes and behaviors of patients with type 2 diabetes mellitus.

Method: This cross-sectional study was carried out in the outpatient clinics. After the written informed consent was obtained, a questionnaire including Sociodemographic Characteristics Form, Clinical Data Form, Diabetes Attitude Scale and Satisfaction with Life Scale was used.

Results: Among the patients $71 \%$ were female. The mean age was $64.7 \pm 11.6$ years. Of the patients, $64.5 \%$ were primary school graduates and $74.3 \%$ were married. According to the distribution of clinical features, $50.3 \%$ had diabetes for 10 years, $25.7 \%$ was using insulin in treatment, $14.8 \%$ had a diabetic foot. The mean score of diabetes attitude scale was $3.61 \pm 0.41$. There was a statistically significant difference between the ages of the patients, their monthly income levels, the duration of diabetes disease and diabetes attitude scale scores. There was a significant difference between satisfaction with life scale scores and age, educational, marital, and family status of patients with diabetes. A positive weak correlation was found between the patients' diabetes attitude scale and life satisfaction scale scores.
\end{abstract}

Conclusion: as the life satisfaction of the individuals who have more positive attitudes towards diabetes is higher, it is important to determine the factors that cause negative and positive attitudes in patients and to support them accordingly.

Keywords: Type 2 diabetes, home care, attitude, life satisfaction

Yazışma Adresi: Yasemin Korkut, Kütahya Sağlık Bilimleri Üniversitesi Tıp Fakültesi Aile Hekimliği AD, Kütahya

E-mail: ykorkut95@yahoo.com

Alınma Tarihi: 14.12.2019 / Kabul Tarihi: 16.03.2020 / Yayımlanma Tarihi: 15.06.2021 
Diyabetes Mellitus (DM), insülin eksikliği ya da insülin etkisindeki bozukluklar nedeniyle karbonhidrat, yağ ve proteinden yeterince yararlanamamak gibi sorunlara yol açan, sürekli tıbbi bakımın gerektiği, kronik bir metabolizma bozukluğudur (1). DM, hem kadın hem de erkeklerde yaşamın herhangi bir döneminde ortaya çıkabilen, ciddi komplikasyonlara neden olan, bireyin yaşam kalitesini önemli derecede etkileyen ve ilerleyen dönemlerde yeti yitimine kadar giden kayıplara yol açan, sık görülen bir hastalıktır (2). DM sıklığı dünya genelinde ve tüm ülkelerde kentleşme sonucunda artan fiziksel inaktivite ve buna bağlı obezite nedeniyle artmaktadır. Bu artış DM'un sağlık kaynakları üzerindeki gelecekteki yükünün belirlenmesi açısından da önemlidir (3). Yaşam tarzındaki hızlı değişim beraberinde gelişmiş ve gelişmekte olan ülkelerin hemen hepsinde özellikle Tip 2 DM (T2DM) prevalansında hızlı bir yükselişi de getirmiştir. 2013 yılında dünya genelindeki diyabetli birey sayısı 382 milyon iken, 2035 y1lında bu oranın \%55 artarak 592 milyona varacağ öngörülmektedir (4). DM birçok organ ve sistemi etkileyen sonuçları olan kronik bir hastalıktır. Yaşam süresini 5-10 yıl kadar kısaltmakta, yaşam kalitesini olumsuz etkilemekte, kardiyovasküler hastalıkların riskini 2-4 kat kadar arttırmaktadır. DM ve buna bağlı gelişen komplikasyonlar bireylerin ve ülkelerin ekonomilerine olan yükü giderek arttırmaktadır (5). DM tedavisinde temel amaç diyabet yönetimini en iyi şekilde sağlamak ve metabolik kontrolü sürdürmektir. DM yönetimi; dengeli bir diyet, uygun egzersiz, ayak bakımı, ilaçinsulin gibi tıbbi tedavi ajanlarınınkullanımı ve kendi kendine kan şekeri takibini kapsayan çok bileşenli bakım aktivitelerinive yaşam tarzı değişikliklerini kapsar (6). Bireylerin hastalıklarını algılaması, hastalığa karşı tutumları, hastalıkla baş etme yöntemleri üzerinde önemli etkiye sahiptir. DM'ye yönelik tutum ve davranışlar ne kadar doğru ve gerçekçi olursa, hem bireysel hem de toplumsal boyutta mücadele o kadar başarılı olacaktır. DM'ye yönelik yanlış ve olumsuz alg1 ve tutumların değiştirilmesi, önleme ve müdahale çalışmalarının bir parçası olmalıdır (7). DM bakımı ve tedavisi sadece hastanede olan bir hastalık olmayıp bu süreç hastaların evlerinde de devam etmektedir.

Evde bakım; yaşlı, engelli, kronik hastalığı olan veya iyileşme sürecindeki kişileri kendi ortamlarında destekleyerek, sosyal yaşama uyumlarını sağlamak, yaşamlarını daha mutlu ve olumlu bir şekilde sürdürerek toplumsal bütünlüğü gerçekleştirmek, bakıma gereksinimi olan kişilerin aile bireyleri üzerine düşen yükünü hafifletmek için kişi ve aileye sunulan psikososyal, fizyolojik ve tıbbi destek hizmetleri ve sosyal hizmetleri kapsayan bakım modelidir (6). T2DM'li birey, hastalık yönetimini ve kontrolünü başarılı bir şekilde sürdürebilmesi için yeterli bilgi, beceri ve pozitif tutumlara sahip olmalıdır. Hastaların olumlu tutum ve davranışlar göstermesi diyabet tedavisinin temelini oluşturmaktadır. Yanlış alışkanlıklar bilindiği takdirde davranışa dönüşmeden düzeltilebilir, bu nedenle diyabetli bireyin eğitim öncesinde tutumları ve yanlış olan alışkanlıklarının değerlendirilmesi önemlidir. Etkin hastalık yönetimi ve kontrolü bireyin uyumluluğunu gerektirir. T2DM'li bireylerin hastalıkla ilgili inanç ve tutumları ile tedavinin gerekliliği için tanımlanan davranış uyumu arasında anlamlı ilişki vardır (8). Hastalık ile başa çıkmak için hastanın iyilik halinin pozitif olmasına, öz bakım becerilerine, hastalık ile ilgili geniş bilgiye, sağlığına ve kendine bakıma dair pozitif tutum göstermesine gereksinim vardır (9). T2DM'li hastaların tedavisini etkileyecek olan tutum ve davranışların belirlenmesine yönelik çalışmalar, daha sonra yapılacak olan girişimlere 1 şık tutacaktır.

Çalışmamızın amacı; T2DM'li hastaların diyabet tutum ve

davranışlarını incelemek ve bu tutum ve davranış değişikliklerinin yaşam doyumuna etkisini belirlemektir.

\section{Gereç ve Yöntem}

Araştırma, 1 Eylül-31 Aralık 2018 tarihleri arasında Evliya Çelebi Eğitim ve Araştırma Hastanesi Evde Sağlık Hizmetleri biriminde yapılmıştır.

Çalışmanın evrenini Kütahya Evliya Çelebi Eğitim ve Araştırma Hastanesi Evde Sağlık Birimine kayıtlı 2000 hasta oluşturmuştur. Epi-info programına göre hesaplanan 183 T2DM hastası çalışmaya alınmıştır. T2DM tanısı için hastane kayıtları esas alınmıştır. En az 1 yıldır T2DM hastası tanısı ile takipli hastalar, düzenli oral antidiyabetik ve/veya insülin kullanan hastalar, 20 yaş üstü olanlar, ciddi nörolojik ve/veya psikiyatrik hastalığı olmayanlar, oryantasyon ve kooperasyon bozukluğu olmayanlar ve çalışmayı kabul edenler çalışmaya alınmıştır. 20 yaş altındaki T2DM hastaları, T2DM için düzenli ilaç kullanmayanlar, ciddi nörolojik ve/veya psikiyatrik hastalığı olanlar, son 1 yıl içinde tanı konmuş hastalar çalışma dışı bırakılmıştır.

Hastalar çalışma hakkında sözel olarak bilgilendirilip yazılı onam formları alındıktan sonra veri toplama aracı olan Sosyodemografik Özellikler Formu, Klinik Veriler Formu, Diyabet Tutum Ölçeği (DTÖ) ve Yaşam Doyum Ölçeği (YDÖ) yüz yüze görüşme tekniği ile uygulanmıştır. DTÖ, T2DM eğitimlerinin etkinliğini, eğitimin etkinliğinde hastaların tutumlarının önemi ile tutum ve davranış arasındaki ilişkiyi açıklamada kullanılmaktadır (10). DTÖ, 7 alt boyuttan oluşan bir ölçektir. Ölçeğin 7 alt boyutu; özel eğitim gereksinimi, hasta uyumuna karşı tutum, T2DM ciddiyeti, kan glikoz kontrolü ve komplikasyonlar, hastanın yaşamına T2DM'nin etkisi, hasta otonomisine karşı tutum ve ekip bakımına karşı tutumdan oluşmaktadır. Ölçek, maddeleri 1'den 5'e kadar olan Likert tipli puanlamaya sahiptir. Puan 3'ün üzerinde ise pozitif tutumu, 3'ün altında ise negatif tutumu ifade etmektedir. Ölçeğin alt gruplarının test-tekrar korelasyon katsayıları 0,52-0,93, Cronbach's Alpha değerleri ise 0,61-0,93 olarak saptanmıştır. Araştırmada, bireylerin yaşamdan aldıkları doyumu belirlemek amacıyla Deiner, Emmons, Larsen ve Griffin tarafından geliştirilmiş olan Yaşam Doyumu Ölçeği (The Satisfaction with Life Scale-SWLS) kullanılmıştır (11). Ölçek Likert tipi 7 dereceli 5 maddeden oluşmaktadır. Her madde "1: Kesinlikle katılmıyorum - 7: Tamamen Katılıyorum" arasında değer almaktadır. Ölçeğin orijinal çalışmasını yapan Diener ve arkadaşları, ölçeğin güvenirliğini Alfa $=0.87$, ölçüt bağımlı geçerliğini 0,82 olarak bulmuşlardır. Ölçeğin Türkçe geçerlik güvenirlik çalışmasını yapan Yetim, ölçeğin Türkiye popülasyonunda güvenirliğini Alfa $=0,86$ olarak saptamıştır (12).

Etik kurul onayı; Dumlupınar Üniversitesi Tıp Fakültesi Klinik Araştırmalar Etik Kurulun'dan 08.08.2018 tarih ve 2018/10-6 karar numarası ile alınmıştır.

İstatistiksel analiz için, SPSS 22.0.0 paket programı kullanıldı. Numerik değişkenlerin normal dağılıma uygunluğu Kolmogrov Smirnov testi ile incelendi. Hipotez testleri olarak Mann Whitney-U, Kruskal Wallis, Spearman Korelasyon testleri kullanıldı. Kruskal Wallis testi sonrası anlamlı fark saptanan gruplardan farkın kaynaklandığ 1 grubun tespiti için ikili karşılaştırmalarda Bonferoni düzeltmesi uygulanmıştır. İstatistiksel olarak önemlilik sınırı $\mathrm{p}<0,05$ kabul edildi.

\section{Bulgular}

Tip 2 Diyabet Hastalarında Hastalık Bilinci - Kayabaşı ve Korkut. 
Çalışmaya 183 hasta dahil edildi. Hastaların \%71'i (n=130) kadın idi. Yaş ortalaması $64,7 \pm 11,6$ yıl olup \%82'si $(n=150) 80$ yaşından küçük, \%18'i (n=33) 80 yaş ve üzerindeydi. Hastaların \%27,3'ü $(n=50)$ okuryazar değilken, \%64,5'inin $(n=118)$ eğitim düzeyi ilköğretim, \%2,7'sinin $(\mathrm{n}=5)$ üniversite seviyesindeydi. Araştırmaya katılanların \% 74,3'ü (n=136) evli, \%24,6 (n=45) dul veya boşanmıştı. Katılımcıların \%2,7'sinin $(\mathrm{n}=5)$ çocuğu yoktu; \%6'sının $(\mathrm{n}=11)$, $\% 30,1$ 'inin $(\mathrm{n}=55)$ 2, \%61,2'sinin $(\mathrm{n}=112) 3$ ve daha fazla sayida çocuğu vardı. Hastaların \%6,6'sı (n=12) tek başına, \%40,4'ü (n=74) 2 kişi, \%53'ü (n=97) 3 ve daha fazla sayıda kişi ile birlikte yaşamaktaydı. Hastaların \%85,8'i (n=157) şehirde yaşamaktaydı. Gelir düzeylerine bakıldığında hastaların, \%37,7'sinin $(n=69)$ 2000TL üzerinde geliri bulunmaktayd.

Hastaların klinik özelliklerinin dağılımına bakıldığında, T2DM tanıSı $<10$ yıl olan hastalar katılımcıların \%50,3'ünü ( $\mathrm{n}=92), 10-20$ yıl olan hastalar \%20,2'sini $(n=37),>20$ y1l olan grup ise \%29,5' ini $(n=54)$ oluşturmaktaydı. Hastaların \%48,6's1 (n=89) oral antidiyabetik, $\% 25,7$ 'si (n=47) insülin, \%25,7'si (n=47) oral antidiyabetik ve insülin kullanmaktaydı. Kan şekeri ortalamaları hastaların \%45,4'ünde $(\mathrm{n}=83)<150 \mathrm{mg} / \mathrm{dl}, \% 44,8$ 'inde $(\mathrm{n}=82) \quad 150-250 \mathrm{mg} / \mathrm{dl}$ arasinda, $\% 9,8$ 'inde $(\mathrm{n}=18)>250 \mathrm{mg} / \mathrm{dl}$ idi. Hastaların HbA1c değerleri ortalamas1 \%8,1 $\pm 1,2$ olup HbA1c değerleri \%57,9'unda ( $\mathrm{n}=106)$ $\% 6,5-8$ arasinda, $\% 42,1$ 'inde $(\mathrm{n}=77) \% 8$ 'in üzerinde idi. Ailesinde T2DM'li birey olanlar hastaları \%55,2'sini $(\mathrm{n}=101)$, olmayanlar \%44,8'ini (n=82) oluşturmaktaydı. T2DM dışı ilaç kullanımı hastaların \%88'inde (n=161) mevcuttu, \%12'si (n=22) T2DM ilac1 dışında bir ilaç kullanmıyordu. Hastaların evde bakım hizmeti alma nedenlerinin büyük çoğunluğunu serebrovasküler olay öyküsü ve senilite oluşturmaktaydı. Hastaların \%36,6's1 3 aydan daha sık kontrol takiplerine devam ederken, \%1,1'i $(n=2)$ 3-6 ay aras1, \% 7, 1'i $(n=13) 6$ aydan daha uzun aralıklı olarak takibe gidiyordu. Hastaların \%55,2'i ( $\mathrm{n}=101)$ takiplerine düzensiz gidiyordu. Diyabetik ayak hastaların \%14,8'inde $(\mathrm{n}=27)$ vard1; \%85,2'sinde $(\mathrm{n}=156)$ diyabetik ayak sıkıntısı yoktu. Hastaların \%56,8'i ( $\mathrm{n}=104)$ diyetine uyduğunu, $\% 43,2$ 'si $(\mathrm{n}=79)$ diyetine uymadığını belirtti. Daha önce diyabet eğitimi alanlar hastaların \%50,3'ünü (n=92) oluşturmaktaydı ve \%49,7'si (n=91) daha önce bir diyabet eğitimi almadığını belirtmiştir. Hastaların \%24'inin ( $\mathrm{n}=44$ ) VKI' i normal iken ( $<25 \mathrm{~kg} / \mathrm{m} 2)$, \%37,7'si $(\mathrm{n}=69)$ fazla kilolu $(25-30 \mathrm{~kg} / \mathrm{m} 2), \% 38,3$ 'ü $(\mathrm{n}=70)$ obez $(>30 \mathrm{~kg} / \mathrm{m} 2)$ idi.

Diyabet tutum ölçeği puan ortalaması 3,61 $\pm 0,41$ idi. Tüm boyutlarda ve toplamda katılımcıların yanıtları pozitif tutumu ( $>3)$ göstermekteydi. Çalışmamızda diyabet tutum ölçeğinin Cronbach Alpha katsayısı 0,84 olarak hesaplanmıştır. Hastaların diyabet tutum ölçeği ve alt boyutları puanları Tablo 1'de sunulmuştur.

Tablo 1. Hastaların diyabet tutum ölçeği ve alt boyutları puanları

\begin{tabular}{|l|c|}
\hline & Ortalama \pm SS \\
\hline \hline DTÖ özel eğitim gereksinimi puanı & $3,86 \pm 0,57$ \\
\hline DTÖ hasta uyumuna karşı tutum puanı & $3,35 \pm 0,45$ \\
\hline DTÖ T2DM'nin ciddiyeti & $3,35 \pm 0,70$ \\
\hline DTÖ kan glukoz kontrolü ve komplikasyonlar puanı & $3,87 \pm 0,57$ \\
\hline DTÖ hasta yaşamına diyabetin etkisi puanı & $3,41 \pm 0,70$ \\
\hline DTÖ hasta otonomisine karşı tutum puanı & $3,54 \pm 0,39$ \\
\hline DTÖ ekip bakımına karşı tutum puanı & $3,76 \pm 0,56$ \\
\hline DTÖ toplam puan & $3,61 \pm 0,41$ \\
\hline \hline
\end{tabular}

Hastalar $<50$ yaş, 50-80 yaş, $>80$ yaş olmak üzere 3 yaş grubuna ayrıldı. Buna göre DTÖ puanlarına bakıldığında 80 yaşın altındaki hastaların puan ortalamaları $3,63 \pm 0,42 ; 80$ yaş ve üzerindeki hastaların $3,47 \pm 0,33$ puandı. Hastaların yaş gruplarına göre DTÖ puanları arasında istatistiksel olarak anlamlı fark bulunuyordu $(\mathrm{p}=0,007)$. Yaş gruplarına göre 80 yaşından küçük olan hastaların DTÖ puanları anlamlı olarak daha yüksekti. Hastaların cinsiyet, eğitim durumu, medeni durum, çocuk sahibi olma durumu, evde yaşadıkları kişi sayısı, yaşadıkları yer ve aylık gelir düzeyi ile DTÖ puanları arasında anlamlı fark yoktu. Hastaların açlık kan glukoz ortalamaları, HbA1c, vücut kitle indeksi, T2DM tedavi türü, T2DM dışı ilaç kullanım durumu, ailesinde T2DM'li hsta olma durumu, diyabetik ayak olma durumu, diyetine uyma durumu ve diyabet eğitimi almış olma durumları ile DTÖ puanları arasında anlamlı fark yoktu.

T2DM süresine göre hastalar 10 y1ldan daha az süredir T2DM olanlar, 10-20 y1l arasında T2DM olanlar ve 20 yıldan daha uzun süredir T2DM olanlar olmak üzere 3 gruba ayrıldılar. T2DM tanıs1 almış olma süresi 10 yıldan az olan hastaların DTÖ puan ortalaması

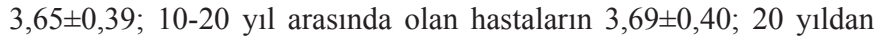

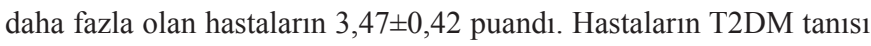
almış olma süreleri ile DTÖ puanları arasında istatistiksel olarak anlaml 1 fark vard $1(\mathrm{p}=0,011)$.

T2DM tanı süresi grupları arasındaki fark T2DM tanısı almış olma süresi 20 yıldan fazla olan hasta grubundan kaynaklanmaktaydı ve 20 y1ldan uzun süredir T2DM hastası olan kişilerin DTÖ puanı diğer gruplardan anlamlı olarak daha düşüktü. Araştırmaya katılan hastaların YDÖ puan ortalamaları 19,9 $\pm 5,85$ puandı. Çalışmamızda yaşam doyum ölçeğinin Cronbach Alpha katsayısı 0,86 olarak hesaplanmıştır.

Araştırmaya katılan hastalardan 80 yaşın altın olanların YDÖ puan ortalamaları $20,58 \pm 5,62 ; 80$ yaş ve üzerinde olanların $16,81 \pm 5,98$ puandı. Hastaların yaş gruplarına göre YDÖ puanları arasındaki fark istatistiksel olarak anlamlıyd $1(\mathrm{p}=0,001)$. Hastalardan 80 yaş ve üzerinde olanların YDÖ puanları 80 yaşın altında olan hastalardan anlamlı şekilde daha düşüktü.

Okuma yazması olmayan hastaların YDÖ puan ortalamaları $18,16 \pm 6,09$; eğitim durumu ilköğretim düzeyinde olanların $20,35 \pm 5,76$; lise ve üzeri olanların $22,13 \pm 4,56$ idi. Hastaların eğitim durumlarına göre YDÖ puanları arasında istatistiksel olarak anlamlı fark saptand $1(p=0,036)$.

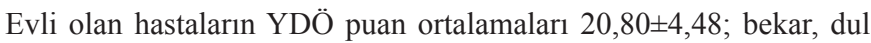


hastaların YDÖ puanları arasında anlamlı fark saptand $1(\mathrm{p}=0,001)$. Evli olan hastaların YDÖ puanları bekar, dul ya da boşanmış olanlardan daha yüksekti.

Hastaların cinsiyet, çocuk sahibi olma durumu, evde yaşadığı kişi sayısı, yaşadığı yer ve aylık gelir düzeyi ile YDÖ puanları arasında anlamlı fark saptanmadi.

Hastaların açlık kan glukoz ortalaması, HbA1c değeri, vücut kitle indeksi, T2DM süresi, kullandığı tedavi türü, T2DM dışı ilaç kullanımı, diyabetik ayak, diyetine uyma durumu, diyetine uyma durumu ile YDÖ puanları arasında anlamlı fark yoktu. Ailede kendisi dışında T2DM'li birey olan hastaların YDÖ puan ortalaması $19,04 \pm 5,37$, olmayan hastaların 20,95 $\pm 6,27$ idi. Ailesinde T2DM'li birey olan ve olmayan hastaların YDÖ puanları arasında istatistiksel olarak anlamlı fark vardı $(\mathrm{p}=0,014)$.

Hastaların YDÖ puanları ile DTÖ puanları arasında pozitif yönlü 
zayıf ilişki mevcuttu. DTÖ alt boyutlarına bakıldığında özel eğitim gereksinimi, T2DM'nin ciddiyeti, hasta yaşamına diyabetin etkisi, ekip bakımına karşı tutum alt boyut puanları ile YDÖ puanları arasında pozitif yönlü zayıf ilişki; kan glukoz kontrolü ve komplikasyonlar, hasta otonomisine karşı tutum puanları ile YDÖ puanı arasında pozitif yönlü çok zayıf ilişki vardı (Tablo 2).

Tablo 2. Hastaların YDÖ puanları ile DTÖ ve DTÖ alt boyut puanları arasındaki ilişki

\begin{tabular}{|l|l|l|}
\hline & \multicolumn{2}{|l|}{ Yaşam Doyumu Ölçeği puanı } \\
\hline & $\mathrm{R}$ & $\mathrm{p}$ \\
\hline DTÖ puanı & 0,309 & $<0,001$ \\
\hline DTÖ özel eğitim gereksinimi puanı & 0,313 & $<0,001$ \\
\hline DTÖ hasta uyumuna karşı tutum puanı & 0,134 & 0,071 \\
\hline DTÖ T2DM’nin ciddiyeti & 0,285 & $<0,001$ \\
\hline $\begin{array}{l}\text { DTÖ kan glukoz kontrolü ve komplikasyonlar } \\
\text { puanı }\end{array}$ & 0,168 & 0,023 \\
\hline DTÖ hasta yaşamına DM'nin etkisi puanı & 0,276 & $<0,001$ \\
\hline DTÖ hasta otonomisine karşı̀ tutum puanı & 0,190 & 0,010 \\
\hline DTÖ ekip bakımına karșı tutum puanı & 0,306 & $<0,001$ \\
\hline
\end{tabular}

DTÖ: Diyabet Tutum Ölçeği, YDÖ: Yaşam Doyum Ölçeği, T2DM: Tip 2 Diyabetes Mellitus, $\mathrm{p}<0,05$

\section{Tartışma}

T2DM'li bireylerde diyabet tutumunu ölçmeye yönelik ülkemizde yapılan çalışmaların birçoğunda özel eğitim gereksinimi alt boyutu en fazla pozitif tutuma sahip alan olarak tespit edilmiştir (10, 1316). Araştırmamızda, Diyabet Tutum Ölçeği puan ortalamaları değerlendirildiğinde ölçeğin ve tüm alt boyutlarının puan ortalamalarının pozitif tutumu gösterdiği saptanmıştır. En güçlü pozitif tutum kan glukoz kontrolü ve komplikasyonlar ile özel eğitim gereksinimi alt boyutundadır. Özel eğitim gereksinimi alt boyutu, T2DM'li bireylerin tedavi ve bakımlarında görevli diyabet ekibi üyelerinin (doktor, diyetisyen, hemşire) T2DM hakkında özel eğitim almaları ve uzmanlaşmaları hakkındaki tutumları ile ilgilidir. $\mathrm{Bu}$ alt boyuttaki yüksek pozitif tutum, diyabet ekibi üyesi olan sağlık bakım çalışanlarının iyi bir eğitim almış olmalarının, T2DM'li hastaları doğru, uygun ve etkili bir şekilde bilgilendirmesinin önemi ve gerekliliğini göstermektedir; ayrıca hastaların bu konudaki beklentilerinin fazla olduğunu göstermektedir. Ayrıca glukoz kontrolü ve komplikasyonları alt boyutundaki yüksek pozitif tutum, T2DM hastalarının glukoz terimini çok sık duymalarından ve bu nedenle de glukoz yüksekliğini çok fazla önemsemelerinden kaynaklanmış olabilir. Diyabet tutumuyla ilgili yapılan çalışmaların çoğunda en düşük puan ortalamasına sahip alt boyut T2DM'nin ciddiyeti alt boyutudur $(6,10,13,14,16,18,67)$. Araştırmamızda da, literatüre benzer şekilde DTÖ’ye ait en düşük puan ortalaması hasta uyumuna karşı tutum puanı ve T2DM'nin ciddiyeti alt boyutlarındadır. T2DM'nin ciddiyeti alt boyutundaki sorular hastaların insülin kullanımına dair olan tutumlarını sorgulamaktadır. Çalışmadan elde edilen bu sonuç insülin kullanmayan bireylerinT2DM'yi daha az önemli bir hastalı olarak görmelerinin nedeni olabilir ve T2DM kontrolünü zorlaştırabilir. Bu durum evde sağlık hizmetleri çalışanlarının T2DM'nin neden olabileceği sorunlar hakkında hasta ve yakınlarının yeterince bilgilendirilmemesinden kaynaklanmış olabilir.

Elkoca'nın çalışmasında, T2DM hastalarının cinsiyetleri ile DTÖ puanları arasında fark saptanmamıştır (15). Ustaalioğlu ve ark ise Genel Tip Derg 2021;31(2)148-152 kadınların erkeklere göre daha fazla pozitif tutuma sahip olduğunu tespit etmiştir (19). Johnson ve ark' nın yaptığı çalışmada kadınların erkeklerden T2DM'nin ciddiyeti alt grubunda daha yüksek puan aldığ1 görülmüştür(20). Özcan'ın çalışmasında ve Javanshir çalışmasında kadınların ve erkeklerin hastanın yaşamına diyabetin etkisi alt boyutunda diğer alt boyutlara göre daha güçlü pozitif tutuma, T2DM'nin ciddiyeti alt boyutunda ise negatif tutuma sahip oldukları saptanmıştır $(10,13)$. Çalışmamızda hastaların cinsiyetleri ile diyabet tutumu arasındaki ilişki değerlendirildiğinde literatüre göre farklı sonuçlara ulaşmıştır. Bu durum çalışmaya alınan hasta popülasyonunun DTÖ sorularını farklı yorumlamalarından veya çalışmaya alınan erkek hastaların sayısının kadınlara göre belirgin olarak daha az olmasından kaynaklanmış olabilir.

Türkiye'de ve yurtdışında yapılmış olan farklı çalışmalarda yaş arttıkça diyabet tutum puan ortalamasının azaldığ 1 görülmüştür (6, 13, 21). Araştırmamızda 80 üzeri yaş grubundaki hastaların DTÖ puanları anlamlı olarak daha düşüktü; ayrıca hastaların yaşı arttıkça DTÖ puanları azalmaktaydı. Bu sonuç yaşlı bireylerin fiziksel ve bilişsel fonksiyonlarının azalması ve yaş ile birlikte yaşadıkları olumsuz deneyimlerin artmasıyla yakından ilişkili olabilir.

Diyabet tutumuyla ilgili yapılan çalışmalarda genel olarak eğitim düzeyi yükseldikçe hastaların Diyabet Tutum Ölçeği ve alt boyutları puanlarının arttığı görülmektedir $(6,13,19)$. Yüksel'in çalışmasında eğitim düzeyinin hastalığın ciddiyetini algılamayı, tedavi ve önerileri yararlı görmeyi etkileyebileceği bildirilmiştir (9). Çalışmamızda eğitim düzeyi ile DTÖ puanları arasında anlamlı fark saptanmamakla birlikte eğitim düzeyi yüksek olanların DTÖ puan ortalamaları daha yüksekti. Bu durum eğitim düzeyi yüksek olan hastaların hastalıkları hakkında daha fazla bilgi edinmek için araştırma yapmalarından ve bunun sonucu olarak daha fazla bilgiye sahip olmalarından kaynaklanmış olabilir.

Gimenes ve ark. çalışmasında da hastalık süresi beş yıldan az olan T2DM hastalarının tedaviye uyumu $\% 80$ iken, beş yıldan uzun süredir tanısı olanlarda \%77,4 şeklinde bulunmuştur (20). Çalışmamızda hastaların hastalık süreleri ile DTÖ puan ortalamaları açısından anlamlı fark vardı ve hastalık süresi daha uzun olan hastaların DTÖ puanları daha düşüktü. Bu durum hastalık süresi arttıkça hastaların olumsuz tecrübelerinin artmasından kaynaklanmış olabilir.

Hasta tutumlarının diyabet yönetimini ve sonuç olarak hastaların metabolik durumunu önemli derecede etkilediği belirtilmektedir. Olumsuz tutuma sahip kişilerin $\mathrm{HbA1C}$ değerinin daha yüksek olduğu, metabolik kontrol düzeyinin daha kötü olduğu görülmüştür (21). Araştırmalara göre olumlu tutuma sahip olan DM'li hastalarda kendine bakım yeteneği, öz bakım becerileri ve metabolik kontrolün daha iyi olduğu gözlenmiştir $(22,23)$. Çalışmamızda da literatüre benzer şekilde hastaların HbAlc düzeyleri artıkça DTÖ ve YDÖ puanlarının azalmakta olduğu ancak aradaki farkın istatistiksel olarak anlamlı olmadığı saptanmıştır.

Akaltun ve ark., ailesinde T2DM'li birey olması durumuna göre Diyabet Tutum Ölçeği puanları değerlendirildiğinde ailesinde T2DM'li birey bulunan hastaların yaşamına T2DM'nin etkisi alt boyutunda pozitif, T2DM'nin ciddiyeti alt boyutunda negatif tutuma sahip oldukları bulunmuştur (6). Yapılan bir diğer çalışmada ise özel hasta eğitimi gereksinimi alt boyutu puan ortalaması ailesinde T2DM'li birey bulunan hastaların daha yüksek olduğu saptanmıştır (13). Çalışmamızda ailesinde T2DM'li birey bulunan ve bulunmayan hastaların DTÖ puan ortalamalarında anlamlı farklılık saptanmamıştır ancak ailede T2DM'si olan hastaların DTÖ puan ortalaması daha

Tip 2 Diyabet Hastalarında Hastalık Bilinci - Kayabaşı ve Korkut. 
düşüktür. T2DM genetik geçişi olan bir hastalıktır veT2DM'li bireylerin \%25-50 gibi değişen oranlarda ailelerinde T2DM'li birey bulunmaktadır $(24,25)$. Ailesinde T2DM'li birey olan hastaların hastalıkla ilgili bilgi düzeyi ve farkındalığı bu nedenle yüksek olabilir; aynı zamanda yakınlarının hastalıkla ilgili olumsuz tecrübelerinden ve yanlış ailesel beslenme alışkanlıklarından etkilenmiş bu durum da onların hastalık tutumlarını olumsuz etkilemiş olabilir.

McAuley ve ark., yaşlılarda sosyal ilişkiler, fiziksel aktivite ve iyilik hali üzerine yaptıkları çalışmada; yaşlılarda sosyal ilişkilerin artmasının yaşam memnuniyetleri açısından önemli bir belirleyici olduğunu belirtmektedirler (26). Mc Culloch'un yaşlıların mental sağlığı ile ilgili yaptığı çalışmada sosyal desteğin mental sağlık için önemli etkenlerden biri olduğu saptanmıştır(27). Mc Nicholas'ın sosyal destek ve olumlu sağl1k uygulamalarına yönelik yaptığ çalışmada, sosyal desteğin öz saygıyı artırdığı ve sağlık algısını pozitif yönde etkilediği bulunmuştur (28). Tayland'da yaşlılarda sosyal desteğin etkilerini inceleyen bir çalışmada da yaşlılarda sosyal desteğin yaşam kalitesini arttırdığı belirtilmektedir (29). Bizim çalışmamızda hastaların DTÖ puanları ile YDÖ puanları arasında hasta uyumuna karşı tutum alt boyutu dışında pozitif yönlü ilişki vardır. Hastaların DTÖ puanı arttıkça YDÖ puanı da artmaktadır. Bu sonuç, hastaların hastalığına dair bilgisi ve uyumu arttıkça yaşamının da olumlu etkilenmesinden kaynaklanmış olabilir. Ayrıca genç, eğitim düzeyi yüksek ve medeni durumu evli olan hastaların YDÖ puanları anlamlı olarak daha yüksektir.

\section{Sonuç}

T2DM; tedavi süreci ilaç tedavisi, diyet tedavisi, egzersiz tedavisi gibi pek çok komponenti olan, hastalarda yaşam tarzı değişikliği gerektiren kronik bir süreçtir. Bu nedenle T2DM hastalarına tedavide bütüncül yaklaşılması gerekir. Tanı anından itibaren kapsamlı hasta eğitimi çok büyük önem taşımaktadır. T2DM'li bireylerin T2DM alanında uzman kişilerce eğitilmesi gerekmekte, bunu sağlamak için diyabet eğitiminde yer alan ekip üyelerinin hem T2DM ile ilgili hem de eğitim teknikleri konusunda donanımlı olması gerekmektedir. Doğru bilginin doğru kaynaklardan doğru şekilde verilmesi ile hastaların hem bilgisine hem de tutumuna yansıması sağlanabilir. Hastaları erken dönemde doğru ve uygun şekilde eğitir, takip edersek daha az olumsuz tecrübe yaşamalarını sağlayabilir, hastalığa uyumlarını ve tutumlarını iyileştirebiliriz. Hastalığa uyumlu ve pozitif tutumu olan bireylerin hayattan memnuniyetleri ve yaşam doyumları da daha yüksek olacaktır. Böylelikle toplumun sağlık durumu sosyal ve mental yönden de desteklenmiş olacaktır.

\section{Kaynaklar}

1. Satman İ, İmamoğlu Ş, Yılmaz C. TEMD Diabetes mellitus ve komplikasyonlarının tanı, tedavi ve izlem kılavuzu. 10. Baskı.Ankara:Miki Matbaacılık San ve Tic Ltd Şti, 2018;15-141.

2. Eren İ, Erdi Ö, Özcankaya R. Tip II diabetik hastalarda kan şekeri kontrolü ile psikiyatrik bozuklukların ilișkisi. Türk Psikiyatri Dergisi 2003;14:184-91.

3. Whiting DR, Guariguata L, Weil C, et al. IDF diabetes atlas: global estimates of the prevalence of diabetes for 2011 and 2030. Diabetes research and clinical practice 2011;94:311-21

4. Türkiye diyabet programı 2015-2020. Available at: http://beslenme.gov.tr/content/files/ diyabet/turkiyediyabetprogrami pdf. 2014.Erişim Tarihi 15Ekim 2018.(Accessed October 15, 2018.)

5. Atmaca HU, Akbaş F, Şak T, ve ark. Diyabetik Hastalarda Hastalık Bilinç Düzeyi ve Farkındalık. Istanbul Medical Journal 2015;16:101-4.

6. Akaltun H, Ersin F. Evde Bakım Hizmeti Alan Diyabetli Hastaların Diyabet Tutum ve Davranışlarının Belirlenmesi. Dokuz Eylül Üniversitesi Hemşirelik Fakültesi Elektronik Dergisi 2016;9:126-133.

7. 2010-2020 Ulusal Diyabet Stratejisi Sonuç Dokümanı. Available at: http://www. nefroloji.org.tr/folders/file/Diyabet_2020_Sonuc_Dokumani.pdf. Erişim Tarihi 20 Ekim 2018. (Accessed October 20,2018.)

8. Karlıdağ R, Ünal S, Yoloğlu S. Hekimlerde iş doyumu ve tükenmişlik düzeyi. Türk

Tip 2 Diyabet Hastalarında Hastalık Bilinci - Kayabaşı ve Korkut.
Psikiyatri Dergisi 2000;11:49-57

9. Yüksel S. Tip 1 ve Tip 2 diyabetik hastaların uyku kalitesi, anksiyete, depresyon ve yaşam kalitesinin değerlendirilmesi. Yüksek Lisans Tezi.Afyon Kocatepe Üniversitesi, Sağlık Bilimleri Enstitüsü, Afyon, 2007.

10. Özcan HŞ. Diyabetli hastalarda hastalığa uyumu etkileyen faktörlerin değerlendirilmesi. Doktora Tezi. İstanbul Üniversitesi, Sağlık Bilimleri Enstitüsü, İstanbul,1999.

11. Diener E, Emmons RA, Larsen RJ, et al. The satisfaction with life scale. Journal of personality assessment 1985;49:71-5.

12. Yetim Ü. Life satisfaction: A study based on the organization of personal projects. Social Indicators Research 1993;29:277-89.

13. Javanshir M. Tip 1 ve tip 2 diyabetli hastaların diyabet tutumlarının değerlendirilmesi Yüksek lisans tezi.İstanbul Üniversitesi, Sağlık Bilimleri Enstitüsü, İstanbul, 2006.

14. Çelik S. Tip 2 diyabetli hastaların bakıma ve tedaviye yönelik tutumlarının ve iyilik hallerinin belirlenmesi. Yüksek Lisans Tezi. Sağlık Bilimleri Enstitüsü, İstanbul, 2002. 15. Elkoca A. Tip 2 diyabetli hastaların hastalığa karşı tutumları ve problem alanlar arasındaki ilișkinin incelenmesi. Yüksek Lisans Tezi.Atatürk Üniversitesi, Sağllk Bilimleri Enstitüsü, Erzurum, 2010.

16. Kartal A, Çağırgan G, Tığlı H, ve ark. Tip 2 diyabetli hastaların bakım ve tedaviye yönelik tutumları ve tutumu etkileyen faktörler. TAF Prev Med Bull 2008;7:223-30.

17. Anderson RM, Hiss RG, Stepien C, et al. The diabetes education experience of randomly selected patients under the care of community physicians. The Diabetes Educator 1994;20:399-405.

18. Kaynak İ, Polat Ü. Diabetes mellitus' lu hastaların tamamlayıcı ve alternatif tedavileri kullanma durumları ve diyabet tutumları ile ilişkisi. Genel Tıp Dergisi 2017;27:56-64.

19. Ustaalioğlu S. Tip 2 Diyabetli Hastalarin Bakim Ve Tedaviye Yönellik Tutum Ve Davranişlarinin İncelenmesi. Yüksek Lisans Tezi.Atatürk Üniversitesi, Sağllk Bilimleri Enstitüsü, Erzurum, 2015.

20. Gimenes HT, Zanetti ML, Haas VJ. Factors Related To Patient Adherence To Antidiabetic Drug Therapy. Rev Latinoam Enfermagem2009;17:46-51.

21. Ünsalavdal E, Özyazıcıŏlu N, Dırık G, ve ark. A comparıson betweenHba1c level and knowledge and attitudes concerning diabetes among type 1 and type 2 diabetics. Acta Medica Mediterranea 2015;31:681-86.

22. Cheng KY, Morris T, Borkoles E, et al. Modelling of diabetesknowledge, attitudes, selfmanagement, and quality of life: a cross-sectional studywith an Australian sample. Health and Quality of Life Outcomes 2015;13:129-39.

23. Chen A, Huang Z, Wan X, et al. Attitudes toward diabetes affect maintenance of drugfree remission in patientswith newly diagnosed type 2 diabetes after short-term continuous subcutaneousinsulin infusion treatment. Diabetes Care 2012; 35:474-481.

24. American Diabetes Association. Diagnosis and classification of diabetes mellitus. Diabetes care 2014;37:81-90.

25. Diyabet Tanı ve Tedavi Rehberi 2017. İstanbul: Türkiye Diyabet Vakfi, 2017;14-67. 26. McAuley E, Blissmer B, Marquez DX, et al. Social relations, physical activity, and wellbeing in older adults. Preventive medicine 2000;31:608-17.

27. McCulloch BJ. The relationship of family proximity and social support to the mental health of older rural adults: The Appalachian context. Journal of Aging Studies 1995;9:65-81.

28. McNicholas SL. Social support and positive health practices. Western Journal of Nursing Research 2002;24:772-87

29. Kuhirunyaratn P, Pongpanich S, Somrongthong R, et al. Social support among elderly in Khon Kean province, Thailand. Southeast Asian Journal of Tropical Medicine and Public Health 2007;38:936-46. 